\title{
Determining Optimal New Waste Disposal Facilities Location by Using Set Covering Problem Algorithm
}

\author{
Rizki Agam Syahputra $^{1 *}$, Andriansyah ${ }^{1}$, Prima Denny Sentia ${ }^{1}$, Riski Arifin $^{1}$ \\ ${ }^{I}$ Industrial Engineering Department Universitas Syiah Kuala Jl. Tgk Abdur Rauf No.7, Banda Aceh 23111 \\ ${ }^{*}$ Corresponding author. Email: Rizkiagamsyahputra@unsyiah.ac.id
}

\begin{abstract}
The inadequacy of an appropriate location and quantity of Temporary Disposal Facility or TPS in Subulussalam city has caused the municipal waste to be disposed in an arbitrary disposal site that mostly lacks the appropriate norm. In response to the necessity to improve waste management issues in the city of Subulussalam, this paper presents a model for determining the TPS location in the Subulussalam city Aceh, Indonesia. This study aims to determine the optimal location and quantity of the TPS by using the Set Covering Problem (SCP) algorithm. Data processing in this study was carried out by using Lingo software version 17.0. The data processing resulted in 23 optimal TPS waste locations with a 5-minute travel time between the TPS location to the waste source. The expected output of this study is to develop a recommendation that can be used to determine the optimum number and location of the temporary municipal waste disposal shelter in the city of Subulusalam.
\end{abstract}

\section{Keywords: SCP Algorithm, TPS, Municipal Waste, Optimal TPS Location}

\section{INTRODUCTION}

Waste management still presents a huge challenge to be solved, especially in developing countries. In the last few decades, the growth of population has contributed exponentially to the increase of the quantity and complexity of the generated wastes produced from household, commercial and industrial entities, especially in developing countries[1]. Population growth in line with the increase of human necessities does not balance with a proper and healthy municipal waste service.

The city of Subulussalam is one of the cities in Aceh, Indonesia, that still require immediate attention regarding waste disposal facilities and location. Data from the Health and Environmental Service (DLHK) of Subulusalam city estimated that the city population grows at an annual rate of $2.7 \%$ with a total land area of $1,391,100 \mathrm{~km} 2$ while the waste piles generated from the city reached 99,07 $\mathrm{m} 3$ per day in 2019[2]. The lack of proper waste disposal facilities in the area causes solid waste to be disposed of and dumped in arbitrary dump sites that mostly lack the appropriate norms. These practices have negative environmental conse- quences ranging from the pollution of natural resources and ecosystems to the emergence of health issues that could lead to long-term public health issues [3]. Furthermore, the city's geographic location in a highland area may lead to landslide disasters that will eventually cause a deeper impact on the city. This indicates that immediate planning is required before the number of municipal wastes reached the maximum capacity and causes more significant problems to the area.

In the process of waste handling, determining the location of the Temporary Waste Disposal Facility (TPS) is one of the vital parameters to be considered. TPS is a place before the waste is transported to the Final Disposal Site (TPA). In general, TPS are placed based on the locations that have the potential to generate large volumes of waste. The type of TPS that is often used as a public waste disposal site in most rural cities in Indonesia is in the form of detachable and nonpermanent truck containers[4],[5]. In determining the location of temporary waste disposal sites, several aspects were evaluated, such as the distance of the polling station to the main road, the distance to the surrounding river, the distance to residents' wells, and 
buffering around the temporary garbage collection[6],[7].

However, it seems that these criteria are not appropriately implemented in Subulusalam city. Evidence suggests that an uneven accumulation of waste occurs in several locations in the city, where the volume of garbage collected at several TPS exceeds the maximum capacity of a waste container, while several other containers are mostly empty [2]. The uneven accumulation of waste is caused by the incorrect placement of TPS in the area, which is difficult to reach in a short time and far from the source of waste. Therefore, this study aims to optimize the number and location of TPS facilities in the city of Subulusalam. In this study, Set Covering Problem (SCP) algorithm is used as a numerical method to allocate the number of facilities needed to cover the most optimum location. SCP is often used to provide a solution in determining the minimum number of facilities and determining the location of facilities to meet the existing demand by at least one facility[8],[9].

This paper is organized as follows: the first stage is to determine the candidate location of the potential TPS within the city. The candidate location was determined by allocating the maximum distance to the demand point while also considering the associated government requirements for TPS facilities location in Indonesia. The second stage is the developed mathematical model to optimize the number of TPS locations in the city of Subulusalam. The optimization process is generated by using Lingo 17.0 software. In this context, the optimization process can lead to creating a new location or eliminating existing facilities. The expected output of this study is to develop a recommendation that can be used to determine the optimum number and location of temporary municipal waste disposal shelters in the city of Subulusalam.

\subsection{Preliminary Data}

\subsubsection{Demand Point}

The demand point in this study is classified as a potential location with high volume of waste produce in one day. The demand point in this study is gathered from the data of Subulusalam city environmental service and direct observation in 2020. Location such as education institution, markets, public transportation terminal and community establishment are considered as potential demand point within the city. Thus, the demand point of municipal solid waste in Subulusalam city in organized in Table 1.
Table 1. Demand point of waste of Subulusalaam city (m3/day).

\begin{tabular}{|c|c|c|}
\hline No & Location & Volume \\
\hline 1 & Terminal & 13.26 \\
\hline 2 & Cut Nyak Dien & 10.22 \\
\hline 3 & Malikulsaleh & 11.04 \\
\hline 4 & Pasar Baru & 18.44 \\
\hline 5 & SMP Muhammadiayah & 8.87 \\
\hline 6 & Teuku Umar & 8.14 \\
\hline 7 & SMAN 1 Simpang Kiri & 7.63 \\
\hline 8 & Abadi & 7.13 \\
\hline 9 & SDN 1 Subulussalam & 8.24 \\
\hline 10 & Pertemuan & 4.86 \\
\hline 11 & Pardosi & 3.00 \\
\hline 12 & Pegayo & 4.27 \\
\hline 13 & Meukem & 5.18 \\
\hline 14 & MAN 1 Simpang Kiri & 2.66 \\
\hline 15 & Chitditiro & 4.23 \\
\hline 16 & Terang Bulan & 5.00 \\
\hline 17 & Panglima Polen & 2.00 \\
\hline 18 & Siti Ambia & 3.72 \\
\hline 19 & Suci Lestari & 1.32 \\
\hline 20 & Nyak Adam Kamil & 1.10 \\
\hline 21 & Cepu Indah & 8.12 \\
\hline 22 & Istiqomah Cepu & 7.05 \\
\hline 23 & SDN 3 Subulussalam & 4.00 \\
\hline 24 & Raja Asal & 3.33 \\
\hline 25 & Bilal Santoso & 2.12 \\
\hline 26 & Belegen & 5.21 \\
\hline 27 & Lae Oram & 4.68 \\
\hline 28 & Tangga Besi & 5.52 \\
\hline 29 & S Barat & 8.24 \\
\hline 30 & Dusun Rahmah & 6.13 \\
\hline 31 & Suka Makmur & 4.72 \\
\hline 32 & Kuta Cepu & 4.12 \\
\hline 33 & Makmur Jaya & 5.04 \\
\hline 34 & Mukti Makmur & 4.75 \\
\hline 35 & Buluh Dori & 4.25 \\
\hline 36 & Pasar Panjang & 3.18 \\
\hline 37 & Sikalonandg A & 3.17 \\
\hline 38 & Sikalonandg B & 3.00 \\
\hline 39 & Penanggalan & 7.17 \\
\hline
\end{tabular}


Table 1. Demand point of waste of Subulusalaam city (m3/day).

\begin{tabular}{|c|c|c|}
\hline No & Location & Volume \\
\hline 40 & Pemancar & 2.26 \\
\hline 41 & Dusun Sila & 2.16 \\
\hline 42 & Lae Bersih & 2.10 \\
\hline 43 & Penuntungan & 2.00 \\
\hline 44 & Jontor & 3.12 \\
\hline 45 & Cepu & 2.52 \\
\hline 46 & Sekelang & 2.14 \\
\hline 47 & Lae Motong & 3.00 \\
\hline 48 & Kampung Baru & 1.56 \\
\hline 49 & Kuta Tengah & 1.89 \\
\hline 50 & Lae Ikan & 2.58 \\
\hline 51 & Belukur Makmur & 2.19 \\
\hline 52 & Binanga & 2.76 \\
\hline 53 & Dah & 1.88 \\
\hline 54 & Geruguh & 2.00 \\
\hline 55 & Harapan Baru & 2.17 \\
\hline 56 & Kampong Badar & 3.09 \\
\hline 57 & Kuala Kepeng & 2.22 \\
\hline 58 & Kuta Beringin & 2.19 \\
\hline 59 & Lae Pemualen & 2.11 \\
\hline 60 & Lae Mate & 2.00 \\
\hline 61 & Mandilam & 1.86 \\
\hline 62 & Muara Batu Batu & 2.29 \\
\hline 63 & Oboh & 3.00 \\
\hline 64 & Panglima S & 2.16 \\
\hline 65 & Pasar Runding & 10.13 \\
\hline 66 & Suak Jampak & 1.73 \\
\hline 67 & Sepaand & 2.04 \\
\hline 68 & Sibuasan & 2.00 \\
\hline 69 & Seperkas & 3.10 \\
\hline 70 & Sibungke & 2.18 \\
\hline 71 & Tanah Tumbuh & 2.16 \\
\hline 72 & Telaand Baru & 2.00 \\
\hline 73 & Tualang & 1.87 \\
\hline
\end{tabular}

\subsubsection{Waste Disposal Facilities Criteria}

According to National standard agency of Indonesia (SNI) number SNI 19-2454-2013, the criteria that needed to be considered for determining waste disposal facilities includes [10].
- Waste facilities need to be located within a place that has the potential to accommodate a large volume of waste

- Candidate TPS location with minimum space requirement of $200 \mathrm{~m}^{2}$

- TPS must be located in an accessible area.

- TPS must not contaminate or pollute the surrounding area.

- TPS has minimal disruption to the aesthetic side of the city.

\section{METHOD}

This study was conducted in the city of Subulusalam which located in the southern part of the province of Aceh, Indonesia. The approach model used in this study is Minimal Covering Location Problem model, this model aims to determine the adequacy and quantity of TPS location by maximizing the amount of waste source that can be served at minimum distance from the potential waste source. The candidate location of TPS was determined by considering the SNI 102454-2013 requirement and the distance from the TPS candidate location to the demand point. The selection of the optimum number and location of the TPS is conducted by using Lingo 17.0 software.

\section{RESULT AND DISCUSSION 3.1.TPS Location Candidates}

The location candidate is evaluated based on the maximum distance to the demand point. This study assumes that the garbage disposal facility is a stationary container system in the form of a permanent building consisting of several types of facilities in accordance with the volume of capacity.

Table 2. TPS candidate location.

\begin{tabular}{|c|l|c|}
\hline No & \multicolumn{1}{|c|}{ Location } & Symbol \\
\hline 1 & Terminal & $x_{1}$ \\
\hline 2 & Cepu Indah & $x_{2}$ \\
\hline 3 & Pasar Baru & $x_{3}$ \\
\hline 4 & Abadi & $x_{4}$ \\
\hline 5 & Pegayo & $x_{5}$ \\
\hline 6 & Terang Bulan & $x_{6}$ \\
\hline 7 & Raja Asal & $x_{7}$ \\
\hline 8 & Lae Oram & $x_{8}$ \\
\hline 9 & Dusun Rahmah & $x_{9}$ \\
\hline 10 & Suka Makmur & $x_{10}$ \\
\hline 11 & Makmur Jaya & $x_{11}$ \\
\hline
\end{tabular}


Table 2. TPS candidate location.

\begin{tabular}{|c|c|c|}
\hline No & Location & Symbol \\
\hline 12 & Mukti Makmur & $x_{12}$ \\
\hline 13 & Pasar Panjang & $x_{13}$ \\
\hline 14 & Sikalonandg Atas & $x_{14}$ \\
\hline 15 & Lae Bersih & $x_{15}$ \\
\hline 16 & Cepu & $x_{16}$ \\
\hline 17 & Jontor & $x_{17}$ \\
\hline 18 & Lae Motong & $x_{18}$ \\
\hline 19 & Kuta Tengah & $x_{19}$ \\
\hline 20 & Kampung Baru & $x_{20}$ \\
\hline 21 & Sikelang & $X_{21}$ \\
\hline 22 & Lae Ikan & $x_{22}$ \\
\hline 23 & Tanah Tumbuh & $x_{23}$ \\
\hline 24 & Belukur Makmur & $x_{24}$ \\
\hline 25 & Lae Mate & $x_{25}$ \\
\hline 26 & Mandilam & $x_{26}$ \\
\hline 27 & Muara Batu Batu & $x_{27}$ \\
\hline 28 & Oboh & $X 28$ \\
\hline 29 & Panglima Sahman & $x_{29}$ \\
\hline 30 & Telaand Baru & $x_{30}$ \\
\hline 31 & Kampung Badar & $x_{31}$ \\
\hline 32 & Kuala Kepeng & $x_{32}$ \\
\hline 33 & Pasar Runding & $x_{33}$ \\
\hline 34 & Suak Jampak & $x_{34}$ \\
\hline 35 & Kuta Beringin & $x_{35}$ \\
\hline 36 & Dah & $x_{36}$ \\
\hline 37 & Sepadan & $x_{37}$ \\
\hline 38 & Sibuasan & $x_{38}$ \\
\hline
\end{tabular}

The specified TPS candidate is expected to cover maximum volume of waste given at the demand point, each TPS candidate is symbolize by $X_{J}, J=$ $1,2,3 \ldots 28$. The selected TPS candidate is presented in Table 2.

\subsubsection{Mathematical models}

In this study, the mathematical model in the set covering problem is presented with one objective function and two constraint functions, where the objective function was developed to identify the minimal number of TPS facilities needed with the emphasis to maximize the coverage of service distance from the facility to the demand point. In addition, the constraint function set ensure that every demand node is covered by at least one facility. Several literatures have formulated the formula for set covering problem in the following way [11], [12]:

Objective Function:

$$
\operatorname{Min} Z=\sum_{\mathrm{j} \in \mathrm{J}} \mathrm{x}_{j}
$$

Constraint Function:

$$
\begin{aligned}
& \sum_{J \epsilon N} x_{j \geq 1 \forall i} \epsilon_{I} \\
& x_{j} \epsilon_{\{0,1\}} \forall_{j} \epsilon_{J}
\end{aligned}
$$

Where:

Z : Objective Function

I $\quad$ Set of demand point type I with the index $i$

$J \quad:$ Set of candidate facility location point with the index $j$

$Y_{i j} \quad$ : The distance between demand point $i$ with candidate location $j$

$Y_{c} \quad$ : Distance Coverage

$N_{i} \quad:\left\{j \mid D_{i j} \leq D_{c}\right\}=$ set of all facilities $j$ which cover location $i$

$\mathrm{X}_{\mathrm{j}} \quad$ : Binary value (1 if the facilities with index $j$ is able to cover demand with, 0 if the opposite)

Based on the minimal covering problem model, the syntax used in Lingo 17.0 processing software is written as follow:

$$
\text { Min=@sum }\left(\operatorname{SET} \_j_{-}(\mathrm{j}): \mathrm{x}(\mathrm{j})\right) \text {; }
$$

Sets listed as $\mathrm{x}(\mathrm{j})$ is regarded as the selected candidate for the TPS location, if $x(j)$ is indexed with the value of 1 then the location is selected and if the $x(j)$ is valued as 0 then the location is not selected. Furthermore, in the constraint function, the determination of the optimum TPS facilities is carried out with two main constraints. To determine the suitable value for optimization result, we may need to consider various factors as constraint point. This study assumes 38 candidate locations and 73 waste sources as the constraint point. Based on the measurement of travel time between demand points and constraint points, the location of demand points $1,8,10$ and 11 can be met by several candidate points, demand points $1,8,10$ and 11 are noted as $\mathrm{x} 1+\mathrm{x} 2+\mathrm{x} 3+\mathrm{x} 4+\mathrm{x} 5+\mathrm{x} 6+\mathrm{x} 71$, this indicate that the demand points at $1,8,10$ and 11 can be covered by 7 candidate points with a maximum distance of 5 minutes. The following model for the constraint function is written as follow:

Constrains 1,8,10,\&11: $x_{1}+x_{2}+x_{3}+x_{4}+x_{5}+x_{6}$

$+x_{7} \geq 1$

Constrains 2,3,4,5,\&24: $x_{1}+x_{2}+x_{3}+x_{4}+x_{6}+x_{7}$ $\geq 1$

Constrains 6: $x_{2}+x_{3}+x_{4} \geq 1$

Constrains 7: $x_{1}+x_{2}+x_{3}+x_{4}+x_{5}+x_{6}+x_{7}$ $+x_{9} \geq 1$ 
Constrains 9: $x_{1}+x_{3}+x_{4}+x_{5}+x_{6}+x_{7}+x_{9}$

$\geq 1$

Constrains 12: $x_{1}+x_{2}+x_{3}+x_{4}+x_{5}+x_{6} \geq 1$

Constrains 13: $x_{1}+x_{3}+x_{4}+x_{5}+x_{6} \geq 1$

Constrains 14: $x_{3}+x_{4}+x_{5}+x_{6}+x_{7}+x_{9} \geq 1$

Constrains 15, 18, 20: $x_{1}+x_{2}+x_{3}+x_{5}+x_{6}$

$+x_{7} \geq 1$

Constrains 16, and 17: $x_{1}+x_{2}+x_{3}+x_{6}+x_{7}$

$\geq 1$

Constrains 19: $x_{1}+x_{2}+x_{3}+x_{6} \geq 1$

Constrains 21 and 22: $x_{1}+x_{2}+x_{3}+x_{4}+x_{7}$

$\geq 1$

Constrains 23: $x_{1}+x_{2}+x_{3}+x_{4}+x_{6}+x_{7}+$ $x_{9} \geq 1$

Constrains 25: $x_{1}+x_{3}+x_{4}+x_{7} \geq 1$

Constrains 26: $x_{2}+x_{4}+x_{6}+x_{7} \geq 1$

Constrains 27 and 31: $x_{8}+x_{10} \geq 1$

Constrains 28: $x_{1}+x_{2}+x_{4}+x_{6}+x_{7} \geq 1$

Constrains 29 and 30: $x_{4}+x_{9}+x_{14} \geq 1$

Constrains 32: $x_{1}+x_{2}+x_{4} \geq 1$

Constrains 33: $x_{11} \geq 1$

Constrains 34: $x_{12} \geq 1$

Constrains 35: $x_{14}+x_{31} \geq 1$

Constrains 36: $x_{13} \geq 1$

Constrains 37 and 38: $x_{9}+x_{14} \geq 1$

Constrains 39: $x_{17} \geq 1$

Constrains 40, 41, 42 and 43: $x_{15} \geq 1$

Constrains 44: $x_{17} \geq 1$

Constrains 45 and 49: $x_{16}+x_{19} \geq 1$

Constrains 46 and 48: $x_{20}+x_{21} \geq 1$

Constrains 47: $x_{18} \geq 1$

Constrains 50: $x_{22} \geq 1$

Constrains 51 and 52: $x_{24}+x_{33} \geq 1$

Constrains 53: $x_{25}+x_{36} \geq 1$

Constrains 54: $x_{19} \geq 1$

Constrains 55: $x_{23} \geq 1$

Constrains 56: $x_{14}+x_{31} \geq 1$

Constrains 57: $x_{23}+x_{24} \geq 1$

Constrains 58: $x_{35} \geq 1$

Constrains 59: $x_{20} \geq 1$

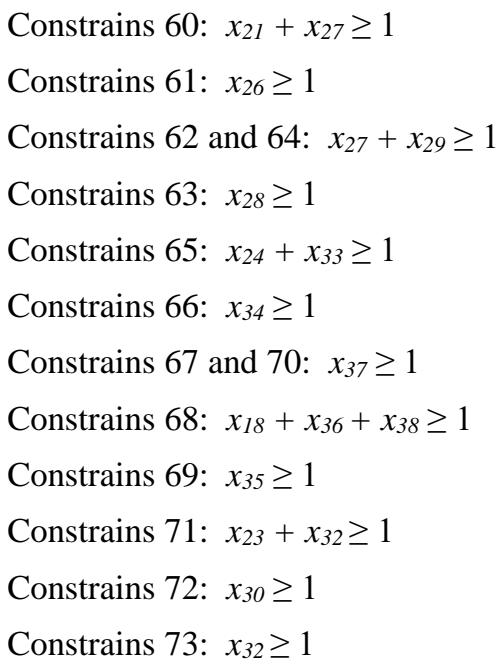

Based on the constraint function with the emphasis that every TPS candidates is expected to cover at least 1 demand point is written as follow:

$$
\begin{aligned}
& \text { @ for(SET_i(i): @ sum(SET_j(j):x(j)*Y(i,j))> } \\
& =1) \text {; }
\end{aligned}
$$

The syntax used in Lingo 17.0 to determine the sensitivity analysis of the model is written as follow: @ for(SET_j(j): @ bin(x(j)));

\subsection{Optimization Result And Analysis}

Based on the calculation generated from Lingo 17.0 software, the selected TPS location to cover the demand point in the city of Subulusalam is presented in Table 3. The result obtained in this study is generated based on the optimal distance from the TPS to the demand point which resulted to the discovery of a 19 new location together with additional 4 existing locations. The selected of the TPS location points are expected to reach 73 existing demand points with a maximum distance of 5 minutes. Furthermore, the result assumes that each demand point is covered by not only one TPS but also can be reached by a nearby TPS. Therefore, each facility covers a percentage of waste demand.

Table 3. Selected TPS.

\begin{tabular}{|c|l|l|l|}
\hline No & Existing TPS & $\begin{array}{c}\text { New TPS loca- } \\
\text { tion }\end{array}$ & District \\
\hline 1 & Pasar Baru & Pasar Baru & $\begin{array}{l}\text { Simpang } \\
\text { Kiri }\end{array}$ \\
\hline 2 & Terminal & Lae Oram & \\
\cline { 1 - 1 } 3 & Suka Makmur & Dusun Rahmah & \\
\cline { 1 - 1 } 4 & & Makmur Jaya & \\
\cline { 1 - 1 } 5 & & Mukti Makmur & \\
\cline { 3 - 3 } & & & \\
\end{tabular}




\begin{tabular}{|c|c|c|c|}
\hline 6 & & Pasar Panjang & \\
\hline 7 & Penanggalan & Lae Bersih & \multirow{6}{*}{$\begin{array}{l}\text { Pe- } \\
\text { nangga- } \\
\text { lan }\end{array}$} \\
\hline 8 & Cepu & Cepu & \\
\hline 9 & & Jontor & \\
\hline 10 & & Lae Motong & \\
\hline 11 & & Kampung Baru & \\
\hline 12 & & Lae Ikan & \\
\hline 13 & $\begin{array}{l}\text { Pasar } \\
\text { Runding }\end{array}$ & Tanah Tumbuh & \multirow{11}{*}{ Runding } \\
\hline 14 & $\begin{array}{l}\text { Kampung Ba- } \\
\text { dar }\end{array}$ & Belukur Makmur & \\
\hline 15 & Oboh & Mandilam & \\
\hline 16 & & Muara Batu-Batu & \\
\hline 17 & & Oboh & \\
\hline 18 & & Teladan Baru & \\
\hline 19 & & Kampung Badar & \\
\hline 20 & & Suak Jampak & \\
\hline 21 & & Kuta Beringin & \\
\hline 22 & & Sepadan & \\
\hline 23 & & Sibuasan & \\
\hline
\end{tabular}

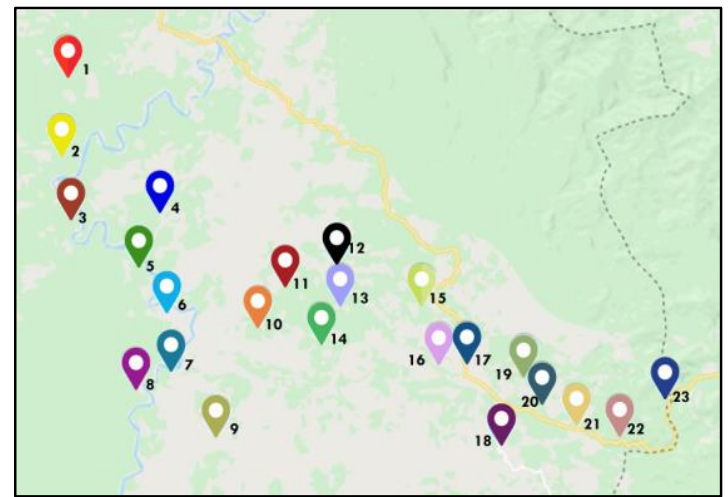

Figure. 1 Selected TPS location.

Information:

1. Suak Jampak

2. Tanah Tumbuh

3. Mandilam

4. Sepadan

5. Sibuasan

6. Muara Batu-batu

7. Belukur Makmur

8. Oboh

9. Kuta Beringin

10. Teladan Baru

11. Mukti Makmur

12. Pasar Panjang
The increase in the TPS stations number generated from the Lingo software may be driven by the growth of the population in the Subulussalam City. The total population of the Subulussalam city in 2017 is estimated at 78.059 people with total production of $93.93 \mathrm{~m} 3$ of waste per day, in contrast the number of populations in 2020 has increased to 90.751 people with a total waste of $99.07 \mathrm{~m} 3$ per day[13]. This indicates that the city requires more TPS facilities to accommodate the increase of wastes from 8 TPS in 2017 to 23 TPS in 2020. Thus, the geographical location of the selected TPS location in the city of Subulussalam is visualized in Fig. 1.

\section{CONCLUSION}

The problem associated with waste management has been one of the major problems requiring constant attention in all major cities worldwide. The growth of population alongside the increase in municipal solid waste produced per day is not coped with adequate TPS facilities in the area. This study utilized a set covering problem method together with Lingo 17.0 to determine a new TPS facilities location in Subulussalam city. Result found that from 8 existing TPS facilities in the city, the model suggests a total of 23 new facilities within the city. The suggested model is based on the distance between the source of waste or demand point to the candidate TPS location. The expected output of this study is to develop a recommendation that can be used to determine the optimum number and location of temporary municipal waste disposal shelters in the city of Subulusalam.

\section{REFERENCES}

[1] Sharma N K and Sharma S, 2020 Municipal solid waste management in developing countries: Future challenges and possible opportunities J. Green Eng. 10, 10 p. 8788-8797.

[2] Hasbullah H Ashar T and Nurmaini N, 2019 Analisis Pengelolaan Sampah Di Kota Subulussalam JUMANTIK (Jurnal Ilm. Penelit. Kesehatan) 4, 2 p. 135.

[3] Schultz P W Bator R J Large L B Bruni C M and Tabanico J J, 2013 Littering in Context: Personal and Environmental Predictors of Littering Behavior Environ. Behav. 45, 1 p. 35-59.

[4] Wibisono H Firdausi F and Kusuma M E, 2020 Municipal solid waste management in small and metropolitan cities in Indonesia: A review of Surabaya and Mojokerto IOP Conf. Ser. Earth Environ. Sci. 447, 1. 
[5] Sihotang D M Tarus K N . and Widiastuti T, 2019 Penentuan Lokasi Tempat Pembuangan Sementara Sampah Menggunakan Metode Brown Gibson Berbasis Sistem Informasi Geografis J. Sist. Inf. Bisnis 9, 2 p. 177.

[6] DAVIS M L and CORNWELL D A, 2008 Introduction to Environmental Engineering Fifth Edition .

[7] Linarti U Fatonah C A and Purwani A, 2020 Development of set covering model for determining the open /closed facilities location and resizing capacity of fasilities IOP Conf. Ser. Mater. Sci. Eng. 909, 1.

[8] Lutter P Degel D Büsing C Koster A M C A and Werners B, 2017 Improved handling of uncertainty and robustness in set covering problems Eur. J. Oper. Res. 263, 1 p. 35-49.

[9] Caprara A Toth P and Fischetti M, 2000 Algorithms for the Set Covering Problem Ann. Oper. Res. 98, 1 p. 353-371.

[10] Badan Standarisasi Nasional, 2002 Tata Cara Teknik Operasional Pengelolaan Sampah Perkotaan ACM SIGGRAPH 2010 Pap. - SIGGRAPH '10 ICS 27.180 p. 1.

[11] Michael Church R L and Meadows M E, 1979 Location Modeling Utilizing Maximum Service Distance Criteria Geogr. Anal. 11, 4 p. 358-373.

[12] Toregas C Swain R Revelle C and Bergman L, 1971 The Location of Emergency Service Facilities September 2014.

[13] BPS Kota Subulissalam, 2021, Catalog: 1102001.1175, Kota Subulussalam. 